\title{
NOTES ON THE ODONATA FROM EAST AFRICA, COLLECTED BY THE CHANLER EXPEDITION.
}

\author{
By Philip P. Calvert.
}

The National Museum, through Dr. Riley, has sent to me for study and identification the Odonata collected by Mr. W. A. Chanler's expedition to East Africa in 1892-93. All of the specimens mentioned below, 19 in number, are from the Tana River. They represent seven species, all well known to occur in Africa. Bibliographical references, in addition to those here cited, may be found in Mr. Kirby's Catalogue of the Odonata (London, 1890).

\section{UROTHEMIS EDWARDSII, Selys.}

Libellula edwardsii, Selys, Explor. Alger. Zool., III, p. 124, Névr., pl. 2, figs. 5, 5a, (1849).

Urothemis edwardsii, Selys, C. R. Ent. Belg., XXI, p. IXv (1878).-Calvert, Proc. U. S. Nat. Mus., XVI, 1893, p. 585, fig. 11.

One male (abdomen, $26 \mathrm{~mm}$.; hind wing, 34.5) agrees witì my figure (of the genitalia) above cited. The coloring of the hind wings differs but slightly from that described for the three males from Congo in the same paper ', viz, that the blackish-brown basal streaks in the subcostal and half of the costal space reaches to the first antecubital. This description quoted speaks of the basal spot on the hind wings as "not reaching the anal border;" "hind" should be substituted for "anal."

A second male (abdomen, $24.5 \mathrm{~mm}$; hind wing, 34) agrees with the fourth male from Congo, described in the same paper by myself. I still think it possible that Libellula sanguinea, Rambur (not Burmeister), may be the younger male of the same species as edwardsii.

A female (hearl, thorax, and first four abdominal segments $=21 \mathrm{~mm}$. long, hind wing 32.5), last six abdominal segments wanting; apparently belongs to the same species as the last-mentioned male; in general it agrees with Rambur's description of his signata, but signata is there stated to have a wing expanse of $8 \mathrm{~cm}$. and to be $5 \mathrm{~cm}$. long.

\footnotetext{
${ }^{\prime}$ Calvert, Proc. U. S. Nat. Mus., XVI, 1893, p. 585.
}

Proceedings of the United States National Museum, Vol. XVIII-No. 1047. 


\section{TRITHEMIS RUBRINERVIS, Selys.}

Libellula rubrinervis, Selys, Rev. Zool., 1841, p. 244; Explor. Alger. Zool., III, p. 120, Névr., pl. I, fig. 5 (1849).

Trithemis rubrinervis, Calvert, Proc. U. S. Nat. Mus., XVI, 1893, p. 585, figs. 8, 9.

Two males, one female. No black on the labium. Abdomen: male 23-25, female 21; hind wing: male 28-30.5, female 29.

\section{CROCOTHEMIS ERYTHRÆA, Brullé.}

Libellula erythroxa, Brullé, Exped. de Morée, III (1), p. 102, pl. 32, fig. 4 (1832).

Crocothemis erythroea, Calvert, Proc. U. S. Nat. Mus., XVI, 1893, p. 585, fig. 10.

Two females, abdomen 24.5, hind wing 31.5; sectors of the triangle of the hind wings separated at their origins. It closely resembles Trithemis ferrugaria, Rambur, of the same country, but differs in the stouter abdomen, and in the vulvar lamina being more nearly erect and not reaching as far as the apex of the tenth abdominal segment. It must be mentioned, however, that the vulvar lamina in these two females is relatively longer than in European specimens of $C$. erythraca. ${ }^{1}$

CACERGATES UNIFASCIATA, Olivier (teste Selys).

Cacergates unifasciata, Calvert, Proc. U. S. Nat. Mus., XVI, 1893, p. 585, figs. $6,7$.

Two males, six females; no trace of the dark-brown band on the wings of the females. Abdomen: male 18, female 16.5-18; hind wing: male 25.5, female 24-25.

\section{DIPLACODES LEFEBVREI, Rambur.}

Libellula lefebvrei, L. parvula, L. flavistyla, Rambur, Névr., p. 112, 116, 117, 1842. Libellula flavistyla, Selys, Explor. Alger. Zool., III, p. 124, Névr., pl. I, fig. 7, 1849.

One male, last four abdominal segments wanting. Genitalia not prominent. Anterior lamina almost flat, projecting less than any other part; margin entire. Hamule small, its apical fourth bifid, inner branch slender, slightly curved but not hooked, apex acute; outer branch

${ }^{1}$ Dr. Karsch writes (Berlin. Ent. Zeit., XXXVIII, p. 23, footnote, 1893), "Calvert recently erects (Trans. Am. Ent. Soc., XIX, 1892, p. 162) a Trithemis erythraa Brullé; this is an untenable mode of designation, since Brauer described a true Trithemis from the Island of Mauritius, very different from Libellula erythraa, Brulle, as Trithemis erythraa, which indeed is vainly to be sought for in Kirby's Synonymic Catalogne of Neuroptera Odonata, London, 1890." The reply to this criticism is that the erythrea from Mauritius described by Brauer (Verh. k. k. zool.-bot. Gesell. Wien, XVII, p. 814, 1867), is a Tramea and not a Trithemis, and is to be found in Kirby's Catalogue, p. 4. One may surmise that Dr. Karsch has merely copied the error of de Borre's "Repertoire Alphabetique," etc. (Mem. Roy. Soc. Sci. Liege (2), XVI, No. 4, 1889), where, on p. 18, C. erythraa, Brauer, with the reference to the Verh. k. k. zool.-bot. Gesell., etc., just given, is incorrectly referred to Trithemis instead of Tramea. Dr. Brauer, in his "Verzeichniss der Neuropteren" of 1868 does not mention his own erythraa. 
wider, apex obliquely truncated. Genital lobe projecting farthest, wider just before the apex than at the base; apex regularly and symmetrically rounded.

\section{ORTHETRUM BRACHIALE, Beauvois.}

Libellula brachiale, Beauvors, Ins. Afr. Amer., p. 171, Nevr., pl. 2, fig. 3, 1805.Selys, Ann. Soc. Ent. Belg., XXXI, p. 21, 1887.-Rambur, Nevr., p. 62, 1842.-Gerstïcker, Mitt. Naturh. Mus. Hamb., IX, 1, p. 5, 1891.

Orthetrum brachiale, Calvert, Trans. Am. Ent. Soc., XIX, p. 162, 1892.

One female, abdomen 31, hind wing 33. The vulvar lamina differs from my description quoted above, in that its apical margin is not "bent toward the abdomen in the middle," but I do not believe that this indicates anything more than a difference in the manner of drying.

\section{ORTHETRUM TRINACRIA, Selys.}

Libellula trinacria, Selys, Rev. Zool., 1841, p. 244; Rev. d'Odon. Eur., p. 4, 1850; Ann. Soc. Ent. Belg., XXXI, p. 19, 1887.-McLachlan, Jour. Linn. Soc. Lond., Zool., XVI, p. 178, 1882.

One female, abdomen 39, hind wing 37, pterostigma 4.5. From De Selys' description ${ }^{1}$ it differs only in the following minor points: The yellow of the rear of the eyes is not spotted with black; the only distinguishable markings on the luteous thorax are a very slender brown antehumeral stripe and an obscure dark line on the upper part of the humeral suture. It agrees with the distinctive specific characters, viz, the abdomen distinctly compressed and vesiculose at base, and the absence of yellow at the base of the hind wings, and it possesses 10-11 antecubitals on the front wings.

Proc. N. M. 95- 10

${ }^{1}$ Rev. d'Odon. Eur., p. 4, 1850. 

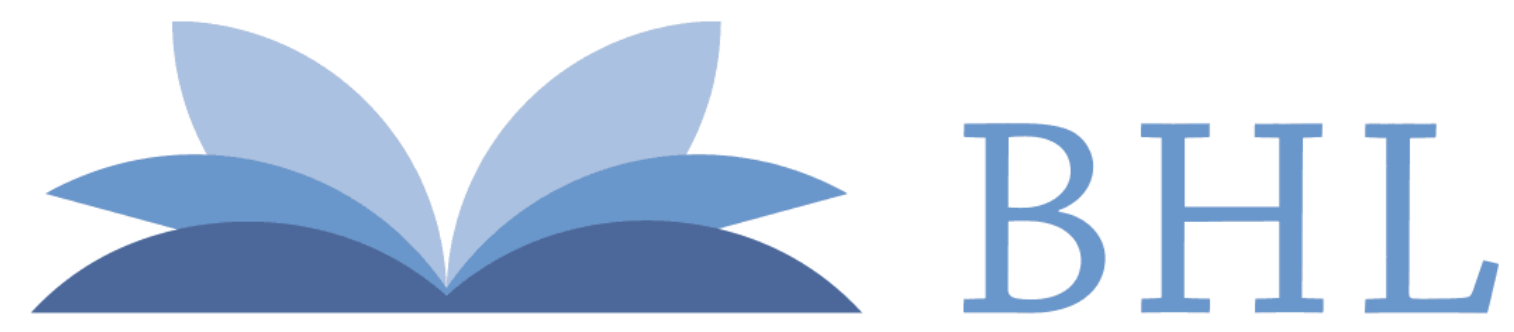

\section{Biodiversity Heritage Library}

Calvert, Philip Powell. 1896. "Notes on the Odonata from east Africa, collected by the Chanler Expedition." Proceedings of the United States National Museum 18(1047), 143-145. https://doi.org/10.5479/si.00963801.1047.143.

View This Item Online: https://www.biodiversitylibrary.org/item/32799

DOI: https://doi.org/10.5479/si.00963801.1047.143

Permalink: https://www.biodiversitylibrary.org/partpdf/5693

\section{Holding Institution}

Smithsonian Libraries

\section{Sponsored by}

Smithsonian

\section{Copyright \& Reuse}

Copyright Status: NOT_IN_COPYRIGHT

This document was created from content at the Biodiversity Heritage Library, the world's largest open access digital library for biodiversity literature and archives. Visit BHL at https://www.biodiversitylibrary.org. 